MATEUSZ SZUREK

\title{
Sprawozdanie z III Międzynarodowej Konferencji Naukowej "Dziecko i nauczyciel w świecie mediów", Wydział Pedagogiczny i Artystyczny Uniwersytetu Jana Kochanowskiego w Kielcach, 22 marca 2017 r.
}

22 marca 2017 r. w gmachu Wydziału Pedagogicznego i Artystycznego Uniwersytetu Jana Kochanowskiego w Kielcach odbyła się III Międzynarodowa Konferencja Naukowa zatytułowana „Dziecko i nauczyciel w świecie mediów". To już kolejne spotkanie podejmujące tematykę dotyczącą oddziaływań mediów na dzieci oraz wykorzystywania mass mediów w edukacji szkolnej. Organizatorem konferencji było Studenckie Koło Naukowe „Mediam” działające w Instytucie Edukacji Szkolnej. Patronat medialny nad wydarzeniem objęły "Wrota Świętokrzyskie” i Fundacja „Nowoczesna Polska”. W spotkaniu wzięli udział studenci oraz doktoranci z wielu ośrodków akademickich, zarówno z Polski, jak i z zagranicy. Obecni byli przedstawiciele m.in. Uniwersytetu Jagiellońskiego, Uniwersytetu Marii Curie-Skłodowskiej w Lublinie, Uniwersytetu im. Adama Mickiewicza w Poznaniu, Uniwersytetu Pedagogicznego im. Komisji Edukacji Narodowej w Krakowie, Uniwersytetu Śląskiego, Uniwersytetu Łódzkiego, Politechniki Warszawskiej i Państwowego Uniwersytetu im. Fiodora Dostojewskiego w Omsku. Wystąpienia prezentowane podczas konferencji wiązały się z kilkoma blokami tematycznymi - dziecko jako widz telewizyjny, funkcjonowanie dziecka w internecie, dziecko w świecie gier komputerowych, dziecko - mały czytelnik, a także wykorzystanie mediów w edukacji. Obrady stały się okazją do naukowej dyskusji, a także do wymiany doświadczeń i kontaktów między naukowcami oraz uczestnikami wydarzenia. 
Konferencję uroczyście otworzyli prodziekan ds. naukowych i artystycznych prof. zw. dr hab. Urszula Ślusarczyk oraz prodziekan ds. studenckich i kształcenia dr Jacek Szkurłat z Wydziału Prawa i Administracji Uniwersytetu Jana Kochanowskiego w Kielcach. Podkreślili oni ważność podejmowanej tematyki dotyczącej mediów, edukacji medialnej oraz kształcenia z wykorzystaniem nowych technologii. Głos zabrała także przewodnicząca komitetu organizacyjnego i przewodnicząca Studenckiego Koła Naukowego „Mediam” - mgr Ewelina Brzyszcz, która powitała wszystkich gości i podziękowała za przybycie.

Obrady plenarne rozpoczęli goście specjalni. Wśród nich znalazła się prof. dr hab. Renata Piasecka-Strzelec z Uniwersytetu Jana Kochanowskiego w Kielcach, która wygłosiła referat pt. Od McLuhana do Castellsa. Przedstawiła główne kierunki podejmowane $\mathrm{w}$ badaniach dotyczących szeroko pojętych mediów. Następny wykład specjalny, wygłoszony przez prof. Małgorzatę Bogunię-Borowską z Uniwersytetu Jagiellońskiego, dotyczył bajkowych modeli opisywania świata społecznego. Wystąpienia przyczyniły się do powstania ciekawej dyskusji dotyczącej prezentowanej tematyki.

W pierwszej sekcji prelegenci poruszali tematy związane z wpływem nowoczesnych technologii na edukację. Przedstawiona została szkolna rzeczywistość opisująca relację uczeń - nauczyciel - smartfon oraz jej wpływ na sukces dydaktyczny w środowisku klasowym. Dodatkowo zastanawiano się także nad oddziaływaniem wybranych polskich seriali telewizyjnych na postawy dzieci i młodzieży - zaprezentowano konkretne przykłady seriali i ich wpływ na funkcjonowanie młodych odbiorców. Inne wystąpienie dotyczyło teatru szkolnego jako uczniowskiego medium komunikacji z publicznością. Przedstawione zostały także możliwości i zagrożenia związane z grami wideo wykorzystywanymi jako adaptacja lektur szkolnych na lekcjach języka polskiego z perspektywy polonisty. Kolejne rozważania dotyczyły mediów w nauczaniu przedmiotów szkolnych.

W drugiej sekcji pojawiły się tematy związane z wykorzystywaniem mediów w logopedii, edukacji architektonicznej czy nauczaniu języka obcego. Zagadnienia podejmowane $w$ tej sekcji miały na celu rozstrzygnięcie czy współczesny logopeda powinien wykorzystywać multimedia w terapii logopedycznej, jak wygląda nauczanie o środowisku zbudowanym przy użyciu współczesnych technologii i w jaki sposób wykorzystywać multimedia podczas lekcji języka obcego. Poruszano także tematykę związaną ze społeczeństwem informacyjnym i jego wpływie na edukację, wpływem gier komputerowych na rozwój dziecka oraz niebezpieczeństwami zagrażającymi dziecku w internecie. 
Prelegenci trzeciej sekcji skupili się głównie na funkcjonowaniu dziecka $\mathrm{w}$ internecie. Tematyka wystąpień obejmowała zagadnienie medialnej hipnozy. Zwrócono także uwagę na aspekt powstawania cyberprzemocy, przedstawiając ją z perspektywy rodziców i nauczycieli. Wpływ internetu na funkcjonowanie dziecka został przedstawiony dwojako - zarówno jako nauka, jak i rozrywka. Duża część wystąpień podejmowała problem zastępowania normalnych relacji społecznych przez wirtualną rzeczywistość. Zagadnienie to zostało poruszone $\mathrm{w}$ referatach nt. użytkowania portali społecznościowych i nadużywania gier komputerowych. Zaprezentowano także pozytywne aspekty korzystania z multimediów, kładąc nacisk przede wszystkim na aspekt edukacyjny.

Osobną sekcję stanowiła sekcja plakatowa. Autorzy posterów naukowych podjęli tematy związane $\mathrm{z}$ wpływem mediów na kształtowanie postaw dzieci i młodzieży. Postery przedstawiały zarówno pozytywny, jak i negatywny wpływ mass mediów, mówiąc o ich możliwościach i zagrożeniach. Podjęto m.in. tematykę wykorzystania urządzeń mobilnych przez najmłodszych, e-edukacji i wpływu bajek na rozwój dziecka. Przewodnim tematem posterów było korzystanie z mass mediów oraz ich wpływ na kształtowanie określonych postaw u dzieci - np. gry komputerowe mogą być przyczyną powstawania postaw agresywnych, jednocześnie jednak media mogą przyczynić się do kształtowania prozdrowotnego trybu życia.

Przewodnim tematem konferencji było ukazanie dziecka i nauczyciela w świecie mass mediów. Wiele uwagi poświęcono tematowi funkcjonowania dziecka i młodzieży w świecie cyfrowym, zwracając szczególną uwagę na pozytywne i negatywne aspekty tego zjawiska. Kolejnym celem konferencji było przedstawienie sposobów na wykorzystanie mediów w pracy nauczycieli i pedagogów. Wystąpienia związane z tym tematem prezentowały możliwości wzbogacenia i uatrakcyjnia procesu nauczania dzięki racjonalnego wykorzystaniu potencjału, jaki daje praca z nowoczesną elektroniką.

Wszystkie prezentowane podczas konferencji wystąpienia odnosiły się do tematyki niezwykle istotnej $w$ dzisiejszych czasach. Nie ulega wątpliwości, że współczesna młodzież bardzo często korzysta z mass mediów, kształtując dzięki nim swoją wiedzę o otaczającym świecie, poglądy czy postawy. Młodzi ludzie wykorzystują media zarówno jako formę rozrywki, jak i edukacji. Rolą nauczycieli staje się nauczenie dzieci prawidłowego i wartościowego korzystania z mass mediów. Dlatego więc badania w zakresie pedagogiki medialnej stanowią bardzo istotną tematykę, która warta jest dalszego opracowania. 